\title{
Der Torsionsindikator
}

\section{II. \\ Die mechanischen und optischen Illethoden \\ zur \\ Derdrehungsmessung}

Von

Dr.-Ing. Paul Nettmann

Mit 50 Abbildungen

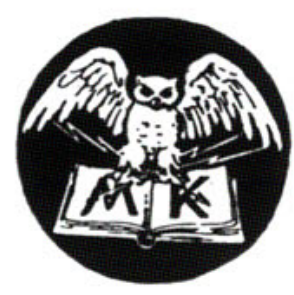

B E R LI N W.

VERLAG VON M. KRAYN 
Copyright 1915 by M. Krayn, Berlin W. 10.

Alle Rechte, namentlich das der Uebersetzung vorbehalten. 